\title{
The Comic Genius in Shaw’s Drama
}

\author{
Shawqi Ali Daghem Mohammed \\ PhD Research Scholar \\ English Dept. \\ Dr. Babasaheb Ambedkar Marathwada University \\ Aurangabad, Maharashtra, India \\ aassubaihi@gmail.com
}

Dr. Shaikh Samad

Professor/Guide, Ex-Principal

Vasantrao Naik College

Dr. Babasaheb Ambedkar Marathwada University

Aurangabad, Maharashtra, India

\begin{abstract}
George Bernard Shaw (1856 - 1950) the socialist, politician, economist, social reformer and the Nobel Laureate playwright, is one of the most venerable authors in the history of literature in general and the theater in particular. He is a great laughter making and thinking motivator, where his comedies always revealed the values of the time. His plays are enjoyable and resonating until today. In this respect, the current article aims to explore Shaw's comic genius and his contributions to the art of comedy as a leading dramatist of the twentieth century. It reveals how he employs jokes and humour to deliver his philosophy and his intellectual judgment on life in a clever and amusing way. The paper describes the
\end{abstract}


development of Shaw's comic and technical style. It focuses on some of Shaw's memorable comedies, which display his comic genius during his career.

Keywords: Shaw, Comedy, Genius, Comic, Modern Drama, Drama of Ideas.

Introduction:

Comedy and tragedy are two dramatic ways of thinking, and therefore they are differentiated by the playwright's attitude toward life. Comedy, as Potts specified, is different from other literary genres in its philosophy rather than its form. Comedy is often defined as comic elements that provoke laughter among the audience. The relationship between comedy and its ability to cause laughter is so popular that the comedy has become synonymous with laughter. There is no doubt that laughter seems to be an inherent component in comedy. However, many critics think that comedy is not simply a type that provokes laughter as many of the greatest comedies have had a sobering influence on their audiences. Potts explains that, "just as the emotions evoked by tragedy are too complex to be called merely sad, so comedy is too complex to be merely funny." (qtd. in Bennett, 250) Undoubtedly there is something more to comedy than just the power to evoke laughter.

Samuel Johnson in his Preface to Shakespeare rejects the common idea that a comedy is any play with a happy ending. He ridiculed the attempts in his time to take tragedies, and by changing the disaster, to transform them dramatically into comedies. The tone of the playwright in relating the subject matter of a play decides the appropriateness of its end. Marriage may be the classical end of a comedy, but marriage may not lead to happiness and pleasure just as death may not always cause sadness or misery. So, it is not the conclusion that decides the tone of the play, but rather the playwright's standpoint toward life. The end of the play may raise more questions for the audience than answers. Shaw's Pygmalion, for example, as great comedy has no happy ending and this is the case in many of his comedies 
as he believes in the workings of the human intelligence that keeps the action and the outcome within the mode of the comic tradition.

The comic style, in dramatic literature, can be set, at least, into nine different types; which are as follows: serious comedies, satirical comedies, fantasy, sentimental comedy, character comedy, melodrama, farce and burlesque. However, the spirit of comedy and its idea are elusive. For many years theorists, critics, and philosophers have sought to understand its forked tail or to explain its gossamer wings.

\section{Shaw's Comic Genius:}

The modern comedy or drama of ideas began at the end of nineteenth century and Shaw is regarded as a pioneer with Wilde, Pirandello, Brecht, and Stoppard. Shaw was the new prophet of ideas who revived the comic spirit and produced a new drama of ideas with dramatic genius. He is considered as one of the greatest and most prolific humorists in the history of English literature along with Shakespeare and Dickens. However, his humour is unlike Shakespeare's or Dickens' humour because Shaw's humour stems from the difference between instinctive behaviour, social institutions and social laws of conduct. His drama of ideas mixed philosophy with enjoyment. It is completely a different thing and the spring of all dramas. It is a discussion drama in which the conflict of ideas and hostile ideals and ideas expose the most acute issues of social and individual morality. The debate in it overshadows the action and characters are only means of ideas. The conflict which is the essence of drama is reached by the conflicting ideas of different characters. Shaw aimed through this drama to educate the people by amusement. This drama, in Shaw's own words, means

the substitution of a forensic technique of recrimination, disillusion, and penetration through ideals to the truth, with a free use of all the rhetorical and lyrical arts of the 
orator, the preacher, the pleader, and the rhapsodist. (qtd. in Bentley, 111)

Drama for Shaw, as he remarks, "is no mere setting up of the camera to nature: it is the presentation in parable of the conflict between man's will and his environment; in a word, of problem.” (Prefaces I, 224) He was different and produced a new kind of drama in a new and effective style. He was the first to deal with drama as an influential power and use the theater as a platform to spread his ideas. Until that time when he started writing for the theater, "there had been no modern British dramatist who took current social, political and religious problems as subjects for plays." (Ward, Candida, 86) In the beginning, the novelty of this drama in theme and style, made it unacceptable; but soon became an important element of Shaw's success.

Initially, Shaw's drama was not greatly valued or understood, but he was eventually appreciated for his genius and is now considered one of the greatest dramatists of modern times. This change of perspectives evolved over time as a result of transformations in social views and a general progress of the theater. The influence of Ibsen on theatrical work changed the usual fare fed to playgoers, teaching them about the role of drama in telling stories that could guide and portray real people and their emotions. These changes influenced the theatergoers to be more open to new ideas, innovations and subjects that Shaw conveyed in his plays. Shaw's contribution to the art of comedy as a leading dramatist of the twentieth century is amply illustrated in his memorable comedies as Arms and the Man, Candida, You Never Can Tell, Man and Superman, Major Barbara, Getting Married, Pygmalion, Androcles and the Lion, and In Good King Charles's Golden Days.

In his long dramatic journey from Widowers' Houses (1892) to Far-Fetched Fables (1948) Shaw got across a very wide range of dramatic styles and forms. In this respect he was a considerable bold creator and an extensive imaginative borrower. He tried to adapt the popular forms and patterns of the Victorian dramatic structures. He helped to establish new 
levels of sophistication in the stage and to revitalise the interaction of drama with life, character, and human destiny. However, in the course of his development, he moved further away from the nineteenth-century standard formula and naturalistic patterns. Shaw expressed himself truly in his own individual style away from the stereotyped form of art. He created his own colourful, open-minded and optimistic stereotype.

In fact, Shaw was a highly staid dramatist and a professional comedian using various forms in his writing by which he angered hundreds, baffled thousands, but delighted the world. He produced varying formulas of drama such as, high comedies, farces, comedies of ideas, of manners, melodramatic, satirical, tragic-comedies. The critics always called his plays as discussions, conversations, economic/social articles, and the like, but when they were produced many of them were genuine theater triumphs, and the audience delighted to the fullest extent. So, the critics took his drama seriously and all criticism and objections died out. Thus, within a few years, his drama was popular and he was well known and successful in the critical and practical meaning of the word.

Definitely, Shaw is a brilliant talker and humorous dramatist. No doubt his plays are full of many intelligent thoughts, humorous conversations, witty comments and intellectual judgements on life; but his "wit is not a mere ornament tacked on to a negligible structure of thought, it is the very bones and sinew of the thought." (Joad, 82-3) He is witty not for the sake of being; but through jokes, epigrams and humour, he tries to capture attention and deliver his philosophy and his intellectual judgment on life in a clever and amusing way. His wit reflects his intelligence and expresses his philosophy.

His perfervid drama of ideas is spectacular through which he aimed at social reform and exposed the incongruity of social institutions in a very charming and pleasant way. He used joke as the sugar-coated bitter pills of satire, irony, sarcasm, etc, to facilitate swallowing without making a wry face; as Meisel explains, "Shaw does not cover his pill with an 
unrelated sugar-coating of conventional drama. Rather he combines edification with a comedy in which the conventions are themselves the butt of the joke, and in which the fun relieves the spectator of an immediate obligation to damn or say 'Amen'." (91) He moved according to audience expectations to persuade them to swallow the pill and then created his own characteristically Shavian effects by turning the expected plot upside down, or withholding the predicted ending. Shaw absolutely produced a real theatrical pleasure with intellectual level, as the audience enjoyed greatly most of his plays.

Shaw, in fact, is a comic genius who perceived the predicament of the society and tried to manifest it in a ridiculous and laughable manner. He aims through his humour and wit to reveal the stupidity, mendacity and falsification in the society in an amusing way. So, wit for him is just an instrument to his purpose which is reforming and correction. He is always joyous and optimistic, and believes in man's goodness. His drama tends to benevolence and betterment and this makes him a unique comedy dramatist. His comic spirit is always honest, bold, courageous and liberal. Most of his plays are comedies of humour, for instance, Pleasant Plays, Three Plays for Puritans, Man and Superman, John Bull's Other Island, Major Barbara, Pygmalion, etc. Shaw, indeed, is a great humorist with a varied and widespread comic spirit. He is laughing even in serious and tragic plays, such as, Unpleasant Plays, The Doctor's Dilemma, Heartbreak House and Saint Joan, in which, he diminishes this seriousness by flashes of humour.

Shaw began with the Unpleasant Plays but the cold welcome of this kind of plays by the audience forced him to change his strategy to Pleasant Plays. In these plays he adapted his techniques, as he found that the change of opinions must come before the consciences modification. In his new plays, he worked to make people think through comedy and laughter but his ideas remained the same, he came, as he declared in his Preface to Plays, Pleasant and Unpleasant, vol. I, "to write plays which, dealing less with the crimes of society, and 
more with its romantic follies and with the struggles of individuals against those follies, may be called, by contrast, Pleasant." (xxvi) This change was a convert from "the social institution, overwhelming individual compunction, to the private imagination, accessible to grace. . . The shift in attention from social crime to romantic folly, from the public institution to the private imagination, was for Shaw an easy shift from effect to cause." (Dietrich, 89) He discovered his magnificent talent for stage comedy, and since then he decided to exploit it to "destroy evil without malice." (Grene, 35) He succeeded in producing his points in a humorous way, which provides laughter and ideas. He always requested his spectators to enjoy his plays and appreciate what lay behind the laughter. He maintains that,

If I make you laugh at yourself, remember that my business as a classic writer of comedies is 'to chasten morals with ridicule'; and if I sometimes make you feel like a fool, remember that I have by the same action cured you of your folly. (Prefaces III, 221)

In 1894, Shaw began his series of what he calls Pleasant Plays with an entirely new play, Arms and the Man, which is new not only in substance but also in spirit. Surely, Arms and the Man is classified to be a high comedy because of its comic paradoxes, humorous and delightful dialogues. Shaw in this play satirises the ideals as being impossible to live up to the human nature and contrary with it. Shaw, also, showed the same ability to write comical and brilliant dialogue in the plays that followed, such as Candida and You Never Can Tell. They are really comedies possessing the same wit and grace that imbue Arms and the Man. Shaw wanted to amuse his audiences and he does this with style.

In Candida (1894), Shaw produced another masterpiece of high comedy and delicate drama. The play exposes the falseness of conventional ideals and loveless marriage. It is a conventional domestic comedy and its plot progresses in a linear way. In Candida, Shaw efficiently adapted the main idea of Ibsen's Doll's House, and counterpoints the typical case 
of a traditional kind of the nineteenth century domestic comedy. It is, indeed, one of Shaw's real genius works, and one of the best plays of the modern theater.

Obviously, Shaw used the tradition of high comedy so successfully in his plays that he produced at the turn of the twentieth century which began with Man and Superman. The characters in these plays move up in the social level so that they have enough time to spend in discussions and dialogues. He achieved the perfect balance between intellect and entertainment. In Man and Superman (1903), for instance, he produced his major philosophy about Creative Evolution and Life Force. It is a philosophic comedy of ideas that presents the meaning of life. It describes love and marriage or sex and romance as a scientific and religious term. Shaw, as Grene indicates, "gives us not a comedy plus a philosophy [as his subtitle suggests], but a comedy philosophized." (55) In fact, the piece has distinct and overlapping meaning by its narratives and drama, language and texts, linguistic and textual devices in addition to philosophical discourses. Shaw weaved the miscellaneous textual materials and interconnected them in an easy and intelligent way. The play is very rich with farce, romance, melodrama, epic, tragedy, dream etc. In Man and Superman Shaw produces himself as a model of the modern writer as a master of different sorts of discourses with suggestive or indirect change and thus makes his play easy to read over various genres and discourses. It is an optimistic comedy that says no to death, war, illness, hate and chastity. Shaw describes the play saying:

I took the legend of Don Juan in its Mozartian form and made it a dramatic parable of Creative evolution. But being then at the height of my invention and comedic talent, I decorated it too brilliantly and lavishly. I surrounded it with a comedy of which it formed only one act, and that act was so completely episodical (it was a dream which did not affect the action of the piece) that the comedy will be detached and played by itself... nobody noticed the new religion in the centre of the intellectual whirlpool. 
(Prefaces II, 429-30)

The comedy, satire and the sparkling dialogues are manifested also through a number of plays that followed Man and Superman, such as John Bull's Other Island, Major Barbara, Getting Married, Misalliance, Fanny's First Play, Pygmalion, The Apple Cart, Too True to Be Good. Major Barbara (1905), for example, is one of Shaw's brightest and most lasting comedies. It is a delightful masterpiece which employs fun to delve into really important issues, such as faith, religion, social status, and ethics. In Major Barbara, Shaw used comedy to throw light on some contradictions and hypocrisies in an attempt to correct people's thinking about such things.

Perhaps, Pygmalion (1912) is considered as Shaw's most famous theatrical and comic masterwork. It is, without doubt, one of the most skillful English literature comedies of the Modern Age. It is a humorous combination of humour and irony. It is a richly complicated play with characters drawn cleverly, replete with humour, irony, and wit. Miles argues that, "the dominant tone of the story is humorous and erotic." (333) The play is vibrant and joyful and its dialogues shine with wit and humour. However, Shaw through this comic spirit was aiming to deal with the class discrimination, socialism, feminism and gender; and to make the people aware of the wrong practices to improve the social conditions. Grene describes the play as, a "Pleasant Play, a Play for Puritans, written out of its time." (101) He goes on to describe the development of Shaw's comic and technical style from Man and Superman to Pygmalion, saying

In the major trilogy of 1901-05, Man and Superman, John Bull's Other Island and Major Barbara, Shaw had developed his own discursive form of comedy of ideas. In the plays that followed [,] he defied audience expectations of formal structure even more recklessly... In Pygmalion, by contrast, Shaw returned to his earlier technique of giving his audience what appeared to be the popular romance they wanted but with 
anti-romantic Shavian treatment. (Ibid)

However, even in the late phase of his very long profession as a playwright, Shaw had not fully finished with the convention that he contributed to revive long before. In The Apple Cart (1928), for example, he shows his brilliance with a Shavian satirical, clever and intellectual comedy. It is one of the most satisfying of Shaw's lesser familiar plays. The play displays its author superiority in his thematic suggestiveness, satire, humour, technical skill and dialectical aptitude. The Apple Cart, as Wilson argues, is "Shaw's best comedy, for it has enough seriousness to make it weightier than any of his other comedies." (qtd. in Mcdowell, 113) In his play In Good King Charles's Golden Days (1939), also, he merged history with high comedy in a most pleasant way. The play, clearly, appears to be more like other masterful plays of ideas, and proves a colourful, thought-provoking work that seems amazingly modern.

In short, Shaw is a dramatist of ideas, concerned basically in ideas, not in personas, plot forming, or passionate complication. His drama shows conflicting perspectives which clash and fight with each other as in a duel game until the strongest of them wins. It would not be an exaggeration to say that Shaw's drama appended a new dimension to the theater that did not exist before. His actual realisation lies in his success in dramatising intellectual attitudes. His personas personify different ideas and can best be considered as ideas that live and move around.

In conclusion, Shaw is a comedy genius in every sense of the word, his reactions are sharp and pointed; but they are never malicious, hateful, savage or personal. His plays are always "witty in form, but they are always humorous in substance." (Sen-Gupta, 145) With all meaning of the word, Shaw's drama is a drama of ideas, and his comedy is a genius comedy. He is,

One of the greatest masters of clear statement that have ever lived, a humorist of the 
first rank, one of the great wits of the world, he knows how to use his wit and humor and clearness to serve his own will, the will to make us disbelieve. (Littell, 110) 


\section{References}

Bennett, Robert A. “Time for Comedy.” The English Journal 53.4 (1964): 248-55.

Bentley, Eric. The Playwright as Thinker: A Study of Drama in Modern Times. Cleveland: World Pub., 1965.

Dietrich, Richard F. British and Irish Drama, 1890 to 1950: A Critical History. Twayne Publishers, 1989.

Grene, Nicholas. Bernard Shaw: A Critical View. Macmillan, 1984.

Joad, C. E. M. Shaw. Gollancz, 1949.

Littell, Philip. “The Bondage of Shaw.” Louis Kronenberger, ed. George Bernard Shaw: A Critical Survey. World Pub. Co., (1953) 105 - 111

Mcdowell, Frederick. “"'The Eternal Against the Expedient”: Structure And Theme in Shaw's The Apple Cart.” Modern Drama 2.2 (1959): 99-113.

Meisel, Martin. Shaw and the Nineteenth-Century Theater. Limelight Editions, 1984.

Miles, Geoffrey. Classical Mythology in English Literature: A Critical Anthology. Routledge, 1999.

Sen-Gupta, S. C. The Art of Bernard Shaw. 3rd ed. Mukherjee, 1957.

Shaw, Bernard. The Complete Prefaces. Edited by Dan H. Laurence and Daniel J. Leary, vol. I, Allen Lane, 1997.

Shaw, Bernard. The Complete Prefaces. Edited by Dan H. Laurence and Daniel J. Leary, vol. II, Allen Lane, 1997.

Shaw, Bernard. The Complete Prefaces. Edited by Dan H. Laurence and Daniel J. Leary, vol. III, Allen Lane, 1997.

Shaw, Bernard. Candida: Edited by A. C. Ward. Orient Longmans, 1995.

Shaw, Bernard. Plays: Pleasant and Unpleasant. I, Constable, 1898. 